\title{
APPLICATION OF THE WILLS ACT 1837 TO NEW ZEALAND: UNTIDY LEGAL HISTORY
}

\author{
David V Williams*
}

The decision of Acting Chief Justice Stephen in McLiver v Macky (1856) was that the Wills Act 1837 (UK) did not apply in New Zealand because New Zealand had been annexed to the British Empire as a dependency of New South Wales. This case and its consequences were discussed in my contribution to the Victoria University of Wellington Law Review special issue in 2010 relating to the New Zealand Law Foundation's "Lost Cases Project". It transpires that Stephen ACJ and counsel in the 1856 case were unaware of the Imperial Act Adoption Act 1839 (NSW) which applied the Wills Act 1837 (UK) to New South Wales from 1 January 1840. This article suggests that, based on the reasoning of the Judge, the 1856 decision would have been the same even if that 1839 Act had been explicitly considered. It would still have been necessary for the New Zealand Parliament to enact the English Laws Act 1858.

\section{A "LOST ACT"!}

A special issue of the Victoria University of Wellington Law Review in 2010 was devoted to articles discussing cases unearthed by the New Zealand Law Foundation's "Lost Cases Project". One of those articles was mine: "The Pre-History of the English Laws Act 1858: McLiver v Macky (1856)". ${ }^{1}$ The English Laws Act 1858 was a declaratory statute. According to the Act's preamble, the laws of England existing on 14 January 1840 "have until recently been applied in the administration of Justice in the Colony of New Zealand, so far as such Laws were applicable to the circumstances thereof". It went on to recite that "doubts have now been raised as to what Acts of the Imperial Parliament passed before" that date are in force in the Colony and "it is expedient that all such doubts should be removed without delay". Section 1, the only substantive section in the Act, read:

* Professor of Law, Faculty of Law, University of Auckland.

1 David V Williams "The Pre-History of the English Laws Act 1858: McLiver v Macky (1856)" (2010) 41 VUWLR 361. 
The laws of England as existing on the 14th day of January 1840, shall, so far as applicable to the circumstances of the said Colony of New Zealand, be deemed and taken to have been in force therein on and after that day, and shall continue to be therein applied in the administration of Justice accordingly.

The doubts mentioned in the preamble arose from a decision of the Supreme Court in the case of McLiver v Macky in 1856 which held that the Wills Act 1837 (UK) did not apply in the Colony of New Zealand. Though not reported in any law report, much of the evidence of witnesses and the submissions of counsel, and the entire judgment of Acting Chief Justice Stephen appeared in September, October and November 1856 issues of The Daily Southern Cross newspaper published in Auckland. ${ }^{2}$

In his summing up to the jury in the first phase of the McLiver v Macky litigation, Stephen ACJ clearly assumed that the Wills Act 1837 actually was in force in New Zealand. He spoke (slightly inaccurately) of "the statute, Vic. 1" and its requirement for wills to be attested in the presence of two witnesses. ${ }^{3}$ This assumption was questioned by the plaintiff in the application for a new trial to overturn a surprising jury verdict. A rule nisi was granted and the defendant was called upon to show cause why a new trial should not be granted. The newspaper report of the respective arguments of counsel on the witnessing of a valid will read as follows: ${ }^{4}$

The fifth point was one of much legal intricacy, but which the Attorney-General entered into at some length. It was simply what Act of Parliament - whether the Wills Act of Vict 1, or previous statutes was in force in the colony. The former requires a will to be attested by two witnesses; the latter by three[.] The learned counsel contended that when New Zealand, in 1840, became a British dependency, the Act of Vict. 1, even although it did not extend to Scotland, became ipso facto the law of the colony. He considered then, that the rule should be discharged, and prayed the Court accordingly.

Mr. Merriman in reply ... contended that the Act of Vict. 1, was not in force here, it not having been adopted by the local legislature. It was a startling conclusion to draw, but he feared that it was so, and that no will was valid, which was not attested by three witnesses.

The argument advanced by Merriman was that for any will to be valid in New Zealand it needed to comply not with the Wills Act 1837, which was not in force in New Zealand, but with the Act 29 Cha 2 c 3 ("An Act for Prevention of Frauds and Perjuryes", 1677). The latter Act required three

2 "Supreme Court, Civil Sittings" The Daily Southern Cross (Auckland, 26 September 1856) at 3; "Supreme Court" The Daily Southern Cross (Auckland, 14 October 1856) at 3; "Supreme Court" The Daily Southern Cross (Auckland, 14 November 1856) at 3; "Supreme Court" The Daily Southern Cross (Auckland, 18 November 1856) at 3-4.

3 "Supreme Court, Civil Sittings" The Daily Southern Cross (Auckland, 26 September 1856) at 3.

4 "Supreme Court" The Daily Southern Cross (Auckland, 14 October 1856) at 3. 
witnesses to be present at the attestation of a will rather than the two witnesses stipulated in the 1837 Act. Stephen ACJ approached the matter this way: ${ }^{5}$

There is now one point remaining to be considered, viz., whether the Act 7 Wm. 4 and 1 Vict. c.26, is in force within this Colony. ... so far as British subjects are concerned, ... those subjects carry with them the Common law of England, and so much of the statute law of England as is applicable to their circumstances and condition, and as was passed prior to those subjects having a Legislature of their own in such colony. The question would then arise, from what period are such Statutes of England to be considered as being in force in New Zealand? When was New Zealand first possessed of a Legislature of its own? The first charter granted to New Zealand is dated, November, 1840. Had there been no statute in force within New Zealand prior to that date, I should have no difficulty in saying that the Act 7 Wm. 4 and 1 Vic. c. 26 having passed in 1837, was in force within this colony, as being applicable to its circumstances. I should regard it as in connection with the statute 29, Charles 2, which is a statute for the prevention of "frauds and perjuries," and which has always been recognised in the West Indian Colonies, as in force there. I believe that that doctrine has been acknowledged in our Courts in England, though I cannot find the authority. But the ground on which it has been held, is that, as the prevention of fraud, or, perhaps more strictly speaking, fraud itself, is punishable at common law, the statute of 29 , Chas. 2, being in affirmance of the common law, would be in force in those colonies, on their being acquired by the Crown, and until they had repealed it by their own Legislatures. Upon this ground, as being in affirmance of the common law, and in connection with the statute of Frauds, I should have held that the Act 7 Wm. 4, and 1 Vict. c. 26., was in force in New Zealand.

The eventual result arrived at, however, was that the Wills Act 1837 was not in force in New Zealand. Why did the judge reach that conclusion? First he inquired of himself, "had New Zealand no Legislature of its own till November 1840?" The answer to that question is that New Zealand did indeed have a colonial legislature applying law to it prior to November 1840. The legislature of New South Wales, to which New Zealand was annexed as a dependency earlier in 1840, was the legislature for New Zealand. Indeed it had passed an Act (3 Vic No 28) specifically applying New South Wales law to the new dependency. ${ }^{6}$ That Act came into force on 16 June 1840. It was continued in force in New Zealand by the very first Ordinance passed by the New Zealand legislature on 3 June 1841 following the erection of New Zealand as a separate colony. ${ }^{7}$ However, this 1841 Ordinance was then repealed when it was enacted on 15 March 1842 that "No Law Act or Ordinance of New South Wales shall hereafter be of any force or effect whatever within the Colony

5 "Supreme Court" The Daily Southern Cross (Auckland, 18 November 1856) at 4.

6 The abbreviation for "Victoriae" in New South Wales Acts and New Zealand Ordinances in the 1840s was usually "Vic" rather than the United Kingdom "Vict", and they were given numbers rather than chapter references.

7 An Ordinance to declare that the laws of New South Wales so far as they can be made applicable shall extend to and be in force in Her Majesty's Colony of New Zealand (1841) 4 Vic No 1. 
of New Zealand" as from 25 April $1842 .{ }^{8}$ I have written elsewhere of joyful celebrations by New Zealand Company settlers in Wellington when news reached them from Auckland that the "penal taint" had been removed from their "free" colony. This included a public dinner celebrating the "Independence of New Zealand", held at Barrett's Hotel. ${ }^{9}$

There has now emerged an unforeseen twist to the legal history that followed the 1842 Ordinance. In 2012 I attended the annual conference of the Australia and New Zealand Law and History Society in Sydney. Listening to a presentation by Stefan Petrow on "A Tale of Caution? The Reception of the English and New Zealand Law of Wills in Australia to 1945", I heard him reel off the dates that each of the colonies in what is now Australia enacted legislation to apply the Wills Act 1837 (UK) in their colony. ${ }^{10}$ I was astonished to hear him mention that in the case of New South Wales there was an Imperial Act Adoption Act 1839. With the benefit of modern digitalised resources to hand, it was simple to locate and read the Act 3 Vic No 5 (NSW). Assented to on 6 August 1839, this Act did indeed adopt and apply the Wills Act 1837 in the administration of justice in New South Wales. Appended to the Act was the full text of what is headed "English Wills Act Adopted, 1 Vic. c. 26." The crucial information for my purposes was that by $\mathrm{s} 2$ the recited Act of Parliament was to come into force in New South Wales from and after 1 January 1840.

Thus as a matter of law the Wills Act 1837 was indeed part of the New South Wales law that was applied to the New Zealand dependency by the New South Wales Act in June 1840. The New Zealand Ordinance in June 1841 continued its applicability in the new Colony of New Zealand. What then was the impact of the 1842 Ordinance that disapplied all New South Wales laws? Before answering that question, I turn to brief comments on 19th century English notions of the laws that apply to British subjects when they settle in new colonies and on reception clauses.

\section{THE BIRTHRIGHT OF BRITISH SUBJECTS}

Serjeant Henry John Stephen was the original compiler of materials that were published in 1834 by Charles Clark as A Summary of Colonial Law. ${ }^{11}$ As was outlined in detail in my 2010 article, Stephen ACJ (a relative of the Serjeant at Law) relied extensively on the Clark treatise in his judgment. Later, HJ Stephen published under his own name four volumes of New Commentaries on the Laws of England (partly founded on Blackstone). Volume I, published in 1841, retained

8 An Ordinance to repeal an Ordinance enacted by the Governor of New Zealand, with the advice and consent of the Legislative Council thereof, whereby the Laws of New South Wales were declared to extend to and be in force in the Colony of New Zealand (1842) 5 Vic No 19, ss 2 and 3.

9 DV Williams "The Annexation of New Zealand to New South Wales in 1840: What of the Treaty of Waitangi?" (1985) 2 Australian Journal of Law and Society 41 at 54-55.

10 S Petrow "A Statutory History of Wills in England and Australia" in GE Dal Pont and KF Mackie (eds) Law of Succession (Chatswood, LexisNexis Butterworths, 2013) at 675-708.

11 C Clark A Summary of Colonial Law (Sweet, Maxwell and Stevens, London, 1834). 
Blackstone's text on the acquisition of colonies by conquest or by cession, or by occupation if they are "desert and uncultivated", along with the notion that: ${ }^{12}$

[I]f an uninhabited country be discovered and planted by English subjects, all the English laws then in being, which are the birthright of every subject, are immediately there in force. But this must be understood with very many and very great restrictions. Such colonists carry with them only so much of the English law as is applicable to their own situation, and the condition of an infant colony; such as, for instance, the general rules of inheritance.

The notion of "an uninhabited country" as used by Blackstone in the many editions of Commentaries on English Law, by Clark in 1834 and by Stephen in 1841 was explained by RobertsWray as late as 1966 in these words: "British subjects who settle abroad in territory not within the jurisdiction of any civilised power take English law with them." ${ }^{13}$ Redolent of imperialist 19th century notions though the term "civilised power" is, in a book published during the mid-20th century era of decolonisation, it was explained by Roberts-Wray that the "birthright" application of English law was appropriate: ${ }^{14}$

In the kind of territory where a Colony could be established by settlement, there was no lex loci or only indigenous law which was quite irrelevant to the needs of the settlers.

As it happens, this was clearly the view adopted by the Colonial Office in 1840. In the despatch from Lord John Russell as Secretary of State for the Colonies informing William Hobson that New Zealand had been erected a separate colony and that he had been appointed its first governor, there was a paragraph on the reasons for establishing a legislature comprised only of Crown appointees: $:^{15}$

Proceeding upon the well-established principle of law that Her Majesty's subjects, settled in a country acquired as New Zealand has been acquired, carry with them as their birthright so much of the law of England as is applicable to their altered circumstances; that fundamental rule has been qualified in the infancy of the Colony by constituting a Legislature nominated by the Crown in New Zealand.

12 HJ Stephen New Commentaries on the Laws of England (partly founded on Blackstone) (Henry Butterworth, London, 1841) vol 1 at 98.

13 K Roberts-Wray Commonwealth and Colonial Law (Stevens, London, 1966) at 540.

14 Robert-Wray, above n 13, at 542. In support of his propositions Roberts-Wray cited William Blackstone Commentaries on the Laws of England (15th ed, T Caell and W Davies, London, 1809) vol 1 at 106-107 and Clark, above n 11, at 4-9 and 52-55.

15 Russell to Hobson, 9 December 1840 in "Copies or Extracts of Correspondence relative to New Zealand" (Cmd 311, 11 May 1841) British Parliamentary Papers (Colonies New Zealand) (Irish University Press, Shannon, 1970) at 146. Enclosures attached to this despatch included: No 1 "Charter for erecting the Colony of New Zealand, 16 November 1840" at 153-155; No 2 "Copy of Letters Patent appointing William Hobson Esq., 24 November 1840" at 155-156; No 3 "Instructions, 5 December 1840" at 156-164. 
It is to be noted that in the quotation above from Clark, the most obvious example of a British subject's "birthright" was "the general rules of inheritance". The law concerning testamentary formalities, therefore, assuredly would be in the category of English law that was immediately in force and would be applicable even in the conditions of an infant colony. Moreover, the Wills Act 1837 would have been a good deal more pertinent to the conditions of the infant New Zealand colony than the Statute of Frauds 1677 (UK). But was the Wills Act 1837 actually part of New Zealand law in 1856 ?

\section{RECEPTION CLAUSES}

The reception of English laws and statutes of general application is a once-only event in the British imperial history of each colony that is declared on a precise date, or retrospectively deemed to have applied from a precise date. Thus the Supreme Court Ordinance for the Colony of Hong Kong asserted that: ${ }^{16}$

Such of the laws of England as existed when the Colony obtained a local legislature, that is to say, on the 5th day of April, 1843, shall be in force in the Colony, except so far as the said laws are inapplicable to the local circumstances of the Colony or of its inhabitants, and except so far as they have been modified by laws passed by the said legislature.

The wording of the English law reception clause for the Colony of Fiji covered: ${ }^{17}$

The common law, the rules of equity and the statutes of general application which were in force in England at the date when the Colony obtained a local legislature, that is to say, on January 2, 1875.

In 1856 in New Zealand, however, there was no reception clause similar to those just quoted. The Supreme Court Ordinances of 1841 and 1844 had provided a commencement date for the criminal jurisdiction of the Supreme Court. Section 6 of the 1841 Ordinance and s 8 of the 1844 replacement were identical:

The Court shall not take cognizance of any criminal case where the offence shall have been committed previous to the fourteenth day of January, one thousand eight hundred and forty.

As I argued in my 2010 article, this provision was, on its face, specific only to criminal cases. The date restriction was mentioned in relation to criminal cases presumably because the New Zealand Ordinances brought to an end the claimed jurisdiction of New South Wales courts to try certain crimes committed in New Zealand, even though New Zealand had been declared by imperial legislation to be "not within His Majesty's Dominions". ${ }^{18}$ That criminal jurisdiction had been claimed and indeed exercised on occasions by New South Wales courts pursuant to the Act 57 Geo

16 Roberts-Wray, above n 13, at 698 (citing the Supreme Court Ordinance (Rev Laws 1950, c 4), s 5).

17 Roberts-Wray, above n 13, at 901 (citing the Supreme Court Ordinance (Rev Laws 1955, Cap 4), s 35).

18 Murders Abroad Act 1817, Act 57 Geo III, c 53, preamble. 
III, c 53 (Murders Abroad Act 1817), the Act 4 Geo IV, c 96 (New South Wales Act 1823) and the Act 9 Geo IV, c 83 (Australian Courts Act 1828). ${ }^{19}$ Any such jurisdiction of New South Wales courts in criminal matters ceased on 14 January 1840. By implication, the other jurisdictions granted to the Supreme Court as a fused jurisdiction court in the new Colony were not necessarily restricted to matters arising after 14 January 1840.

What then was the English law reception date for New Zealand? After the English Laws Act 1858 was enacted in New Zealand, the approach of the courts was clear. In the words of Johnston J in 1878:20

[W]e must suppose that we have lying open before us the whole common law and Statute law of England in force on the terminal day; and of that great body of law, every provision which was then applicable to the circumstances of the Colony is to be deemed to have been solemnly adopted.

In 1856, though, there was no specified "terminal day". The "great body" of English law, or any element of it, could not be repealed, amended or replaced by a United Kingdom statute enacted on a date later than the inception of a colony. Later enacted United Kingdom statutes could only be incorporated in a colony by the passage of a local statute. An example of such a later statute was the New Zealand legislature's English Acts Act 1854. This Act explicitly applied a number of post-1840 United Kingdom Acts to New Zealand - including, as it happens, the Wills Amendment Act 1852 (UK). So, as at 1856, whilst the 1852 Wills Amendment Act certainly applied here, was the principal 1837 Act (without which the 1852 Act made little sense) in force in the Colony? Stephen ACJ held that it was not.

\section{THE REASONING OF STEPHEN ACJ}

This was his reasoning: ${ }^{21}$

The Charter of November, 1840 was granted by virtue of the Act 3 and 4, Vic., (August 1840)[.] That Act is entitled: "An Act to continue until the 31st day of December, 1841, and to the end of the then next session of Parliament, and to extend the provisions of an Act to provide for the administration of justice in New South Wales and Van Dieman's Land, and for the more effectual Government thereof, and for other purposes relating thereto;" and it recites an Act, passed in the 9th Geo. 4, entitled "an Act to provide for the administration of justice in New South Wales and Van Dieman's Land, and for the more effectual Government thereof, and for other purposes relating thereto;" and it also recites that "that last

19 See David V Williams "The Foundation of Colonial Rule in New Zealand" (1988) 13 NZULR 54 at 55. See also EJ Tapp Early New Zealand: A dependency of New South Wales, 1788-1841 (Melbourne University Press, Carlton, 1958) at 71.

20 Highett $v$ McDonald (1878) 3 NZ Jur (NS) 102 (SC) at 104.

21 "Supreme Court" The Daily Southern Cross (Auckland, 18 November 1856) at 3 (emphasis in original). 
mentioned Act had been since continued, and in the last session of Parliament had been further continued, with certain amendments."

The first section then continues the last recited Act, until 31st December, 1841.

The second recites thus: "Whereas the said colony of New South Wales is of great extent, and it may be fit that certain dependencies of the said colony should be formed into separate colonies, and provisions should be made for the temporary administration of the Government of any such newly erected Colony;" and then enacts that it shall: "be lawful for her Majesty, by letters patent, \&c., to erect into a separate colony or colonies, any Islands, which now are or which hereafter may be comprised within, and be dependencies of the said Colony of New South Wales." The Charter of 1840 recites this last recited Act, and also recites, "and whereas the Islands of New Zealand, at the time of passing the above recited Act, were comprised within, and were dependencies of the said colony of New South Wales," and goes on to say, "in pursuance of the said recited Act, and in exercise of the powers thereby in us vested," her Majesty did, by her said charter, erect the said Islands of New Zealand into a separate colony.

It is clear, therefore, that New Zealand was, at the time of the passing of the Act of $7 \mathrm{Wm} .4$ and 1 Vict. c. 26., a dependency of New South Wales, and subject to the Legislature of New South Wales, and consequently that Statute not being in force in New South Wales when the 9th Geo. 4 was passed, nor made to be so there when the Charter of 1840 was granted, it never was in force within this Colony.

If, however, there was an Act, passed in New South Wales, at any time before the grant of that Charter, to extend the Act of $7 \mathrm{Wm} .4$ and 1 Vict. c. 26 to New South Wales, then the Ordinance of New Zealand, September 2, No. 19 (passed 15 March, 1842.) by which "All Laws, Acts, or Ordinances of New South Wales, which theretofore had been in force in this Colony, were repealed," would have repealed it. But the 7 Wm. 4 \& 1 Vict. c. 26 was not, I believe, then in force in New South Wales; and the second section of this last Ordinance enacts, that, "No Law, Act, or Ordinance of New South Wales shall hereafter be of any force or effect whatsoever, within the Colony of New Zealand."

The result then is that as the Act, now under consideration, being passed in 1837, was not in force in New South Wales, when the 9th Geo. 4, (1827) was passed; it was not in force in New Zealand, which, was then a dependency of that Colony; and, as it continued such dependency until the Charter of 1840 , the Act could not be in force in New Zealand, unless it had been enacted by the Legislature of New South Wales in that interval, or at least before the repealing Ordinance of 1842.

Readers aware that Australians celebrated a bicentenary in 1988 might note that the establishment of the penal colony when the first British convoy reached the continent on 26 January 1788 was not considered by Stephen ACJ to be the date of reception of English law. Rightly so the administration of the penal colony in its earliest years bore but faint resemblance to the norms of English law. The reception statute mentioned by the Judge - 9 Geo 4, c 83 - was not in fact enacted as the Judge stated in 1827. After passage through the New South Wales legislature in 1827, the 
Governor reserved it for Her Majesty's assent or disallowance in London. It came into force on the date of the royal assent - 25 July $1828 .^{22}$ Thus 25 July 1828 was the reception date for English law in New South Wales. On the Judge's reasoning that was the reception date for the New Zealand dependency as well. The Wills Act 1837 was not part of New Zealand law.

\section{WHAT IF THEY HAD KNOWN OF THE 1839 NSW ACT?}

There is no way of ascertaining why Merriman, Whitaker and Stephen ACJ appeared to have no knowledge of the Imperial Act Adoption Act 1839 (NSW). What is plainly evident is that none of them refer to it and all of them assume that there was no relevant New South Wales law on point. Would the decision of the Supreme Court in 1856 have been different if the Court had been alerted to the Act applying the Wills Act 1837 to New South Wales from 1 January 1840? I think not. After the passage in his judgment quoted above, Stephen ACJ continued: ${ }^{23}$

But if it had been enacted by [the NSW legislature], and thereby had formed part of the New South Wales laws, in force within New Zealand, then the repealing Ordinance of 1842 would have repealed it, so that, quácunque viá datum, the Act $7 \mathrm{Wm} .4$ and 1 Vict. c. 26, not having been passed within this

Colony, by a Legislature of its own, it is not in force in New Zealand.

On the reasoning of the Acting Chief Justice, if he had been aware of the Imperial Act Adoption Act 1839 (NSW), the Wills Act 1837 would have been part of the New South Wales law that was applied to the New Zealand dependency by the Act 3 Vic No 28 on 16 June 1840. It would have been continued as part of New Zealand law when the Ordinance 4 Vic No 1 (NZ) was passed on 3 June 1841. However, when the Ordinance 5 Vic No 19 (NZ) came into force on 25 April 1842 not only was New Zealand freed from the "penal taint" of New South Wales laws but the Imperial Act Adoption Act 1839 (NSW) too would have been disapplied along with all the rest of the New South Wales laws. The Wills Act 1837 therefore would have ceased to be part of New Zealand law from 1842 until 1856. It was not in force when McLiver v Macky was decided in 1856.

Having ceased to apply since 1842, the Wills Act 1837 became part of New Zealand law again when the English Laws Act 1858 retrospectively declared a precise reception date for English law in New Zealand. It was "laws of England as existing on the 14th day of January 1840" that, in Johnston J's words, were "deemed to have been solemnly adopted". ${ }^{24}$ This was the day when the New South Wales Governor, George Gipps, privately swore in William Hobson to be Lieutenant Governor of the New Zealand dependency and signed three proclamations relating to the dependency. The English Laws Act was re-enacted in 1908 in the parliamentary consolidation of statutes in that year. When the Imperial Laws Application Act 1988 was passed, the Wills Act 1837

22 Williams, above n 19, at 63.

23 "Supreme Court" The Daily Southern Cross (Auckland, 18 November 1856) at 3.

24 Highett v McDonald, above n 20. 
was explicitly mentioned in the schedule of imperial laws still in force. It ceased to be part of New Zealand law only when the Wills Act 2007 came into force.

\section{UNTIDY LEGAL HISTORY}

A modern law student inquiring into testamentary formalities might well turn to a textbook published in 2011 on comparative succession law to find a chapter on Australia and New Zealand law written by Nicola Peart. In this chapter Peart mentioned the history of Imperial Act Adoption Acts that had applied the Wills Act 1837 (UK) in the various Australian colonies. She noted that there are eight similar but not uniform statutes regulating wills now in force in the various jurisdictions of federal Australia. She then made this bald assertion: ${ }^{25}$

New Zealand, by contrast, is a unitary state. As it was only colonized in 1840, the Wills Act 1837

applied to New Zealand from the date of colonization until it was replaced by the Wills Act 2007.

It does not matter much now in a practical sense, but the ins and outs of legal history, as has been demonstrated, were far from as simple and tidy as is stated in that quotation.

25 N Peart "Testamentary Formalities in Australia and New Zealand" in Kenneth GC Reid, Marius J de Waal and Reinhard Zimmermann (eds) Testamentary Formalities (Oxford University Press, Oxford, 2011) at 334. 